\title{
SDHD wt Allele
}

National Cancer Institute

\section{Source}

National Cancer Institute. SDHD wt Allele. NCI Thesaurus. Code C97780.

Human SDHD wild-type allele is located in the vicinity of $11 \mathrm{q} 23$ and is approximately $33 \mathrm{~kb}$ in length. This allele, which encodes succinate dehydrog enase [ubiquinone] cytochrome b small subunit, mitochondrial protein, is involved in the localization of enzyme activity of the electron transport chain. Mutation of the gene is associated with hereditary parag ang lioma type 1, pheochromocytoma, Carney-Stratakis syndrome and Cowden-like syndrome. Mutations also may be associated with intestinal carcinoid tumor. 